DOI: 10.35218/armca.2019.1.07

\title{
Self-portrait in the Middle Ages
}

\author{
Ioana Palamar*
}

\begin{abstract}
Self-portrait has always been a complex artistic genre since its appearance until gaining its autonomy, because it reflects the artist's mental and artistic development level to a great extent. If in Ancient times, self-portrait was considered just a simple documentary evidence, later it became a real symbol of the painter's identity and also an essential way of expressing one's deepest feelings which seemed to be forgotten, but they were actually stored in one's subconscious level. The article highlights specific ways of selfrepresentations both in universal and in Romanian medieval art, which mark the beginning of self-consciousness, from a psychological point of view, and the beginning of a three dimensional representation, from a technical point of view, which indicates the beginning of profane painting that is different from the Byzatine style characterized by specific representation canons.
\end{abstract}

Keywords: Middle Ages, self-portrait, facial expressions, Byzantine painting, profane painting

\section{Introduction}

Generally speaking, self-portrait emerged due to a strong psychological need to express some hidden experiences which are apparently forgotten, but stored in our subconscious. The purpose consists in presenting the development of self-portraits both in the history of universal and Romanian art which are analyzed from a historical point of view by making some connections with the Middles Ages Period, but also from a psychological point of view according to the structure: Id - Ego - Superego which involves the decipherment of certain symbols expressed by instincts that are denied by our consciousness, concealed in the unconsciousness and subsequently outsourced indirectly ${ }^{1}$. Self-portrait stands for a symptomatic manifestation of our unconsciousness ${ }^{2}$ and brings to light the desires, regrets

\footnotetext{
${ }^{*}$ Teaching Assistant, PhD. George Enescu National University of Arts

${ }^{1}$ Constantin Enăchescu, Tratat de psihanaliză și psihoterapie [Treaties on Psychoanalysis and Psychotherapy] , Maria-Elena Druță (editor), "Didactică și Pedagogică” Publishing House, R.A. - Bucharest, 1998, pp. 34-35.

${ }^{2}$ Cristian Nae, Moduri de a percepe. $O$ introducere în teoria artei moderne și contemporane [Ways of Perceiving. An Introduction to the Theory of Modern and Contemporary Art], Oana Maria Nae (red.), Arte Publishing House, Iași, 2013, p.86.
} 
or traumas repressed by our consciousness, whose interpretations are difficult to convey:

Thus, dream and artistic creation as well, are "enigmas which need to be deciphered», because both in dream and in art, there is a latent content which is expressed in a derivative way through the artistic forms the artist resorts to and because, in both situations, the intervention of consciousness limits free expression. ${ }^{3}$

Self-portrait has a complex history, judging its evolution as an artistic genre from its emergence to its autonomy, both in universal and Romanian art history, reflecting the artist's status as well as his mental and artistic evolution. If the painter initially considered self-portrait a simple documentary-artistic attestation, then this artistic genre became a real identity symbol and an indispensable way of expressing the most hidden experiences, apparently forgotten, but stored in the subconscious. The trajectory is complex, so that self - portrait evolved from a contextual self-projection ${ }^{4}$, a role-playing game ${ }^{5}$, an independent genre ${ }^{6}$, a creation as a show ${ }^{7}$, to selfportrait in a mirror ${ }^{8}$, as a performative object ${ }^{9}$ or as a hidden ${ }^{10}$ or abstract one. ${ }^{11}$ The process of self-knowledge requires solitude and the artist Leonardo da Vinci considered that the others disturb the tranquility of the soul which is essential for a better knowledge of one's inner world: "If you are alone, you belong entirely to yourself. If you are accompanied by even one companion, you belong only half to yourself or even less in proportion to the thoughtlessness of his conduct and if you have more than one companion,

\footnotetext{
${ }^{3}$ Ibidem, p.87, apud Sarah Kofmann, L'enfance de l'art. Une interpretation de l'esthétique freudienne [The Childhood of Art. An Interpretation of Freudian Aesthetics], Payot Publishing House, Paris, 1970.

${ }^{4}$ Victor Ieronim Stoichiță, Instaurarea tabloului. Metapictura în zorii Timpurilor Moderne [The Instauration of Painting. Metapainting at the dawn of Modern Times], translation from French made by Andrei Niculescu, "Meridiane" Publishing House, Bucharest, 1999, pp. 232242.

${ }_{5}^{5}$ Masquerade: Role Playing in Self-Portraiture - Photographs from the Audrey and Sydney Irmas Collection, Art of the Americas Building, October 12, 2006-January 7, 2007

$<$ http://www.lacma.org/art/exhibition/masquerade-role-playing-self-

portraiture $\% \mathrm{E} 2 \% 80 \% 94$ photographs-audrey-and-sydney-irmas $>$ (29.05.2016, 12:48).

I. C. editor artline.ro, Autoportretul, o incursiune în timp şi spaţiu [Self-portrait, a, published on 22.08.2013, 17:08

$<\mathrm{http} / /$ www.artline.ro/Autoportretul--o-incursiune-in-timp-si-spatiu-32158-1-n.html>

22.08.2013 (29.05.2016, 12:55).

${ }^{7}$ Victor Ieronim Stoichiţă, op.cit., pp. 262-284.

${ }^{8}$ Ibidem, pp. 250-262.

${ }^{9}$ Alex Greenberger, The Art of Disguise? How Self-Portraiture Went Undercover, 25.11.2013 $<$ http://www.artspace.com/magazine/art_101/art_market/self_portraiture-51776>, (29.05.2013, 13:06).

${ }^{10}$ Geta Brătescu. Atelierul, Alina Şerban (ed.), traduceri: Vlad Arghir, Alistair Ian Blyth, Laura Ionică, Claudia Rada, traducere din poloneză Krzysztof Kosciuczuk, Ed. Sternberg Press, Kontakt, Berlin, Asociaţia pepluspatru, București, 2013, p. 79.

11 Abstract portraiture, <https://ro.pinterest.com/jennaelisha/abstract-portraiture/> (29.05.2016, 15:03).
} 
you will fall more deeply into the same plight."12 Johann Wolfgang Goethe considers that "Self-knowledge comes from knowing other people"13, thus bringing the self-knowledge process to a balanced level. The reason behind self-portrayal is the desire of individualization and self-valorization of which one is more or less conscious of, having its roots in childhood since the moment the human being starts showing interest in one's own physiognomy. ${ }^{14}$ Self-awareness since the age of 18 months ${ }^{15}$, as well the awareness of one's own feelings and thoughts ${ }^{16}$ since the age of 4 or 5 years old reveal an intense need for self-knowledge which develops later in life. It is not accidental the usage of mirror in the artistic creations of the $20^{\text {th }}$ century, in this respect, it is relevant Michelangelo Pistoletto's self-portrait which is part of the series entitled Mirror Paintings which consists in integrating the natural-size of his own image on the surface of a mirror. The main aim is to include external characters as well as other elements from the environment in his artworks, in order to deal with the hazard. According to Lacan's concept, the ego projection in a mirror is illusory, being rather understood as a self-denial or as an utopia of self-knowledge ${ }^{17}$ and Pistoletto has created a connection with this idea which is about creating a fictional (self-)portrait. It is considered that self-knowledge is partly fulfilled and a human being is defined by an endless mountain of secrets which cannot be fully decrypted. From a psychological point of view, the imperative need for self-portraiture is explained by the desire to unconsciously compensate the lack produced by the loss of the original state ${ }^{18}$ when the baby suffers a separation from his mother's body at birth. This nostalgia for unity, symbolized by the artistic creation (self-portrait), can also be connected to IdEgo relationship which forms a unitary whole ${ }^{19}$ in the prenatal stage, as these

12 Leonardo da Vinci $>$ Quotes $>$ Quotable Quote, $<$ http://www.goodreads.com/quotes/131743-if-you-are-alone-you-belong-entirely-to-yourselfif $>(20.08 .2016,12: 53)$.

${ }^{13}$ Self-Knowledge Quotes, Johann Wolfgang von Goethe,

$<$ http://www.brainyquote.com/quotes/keywords/self-knowledge.html $>(20.08 .2016,12: 57)$.

14 Matthias Wildermuth, Entwicklungs- und Störungsmodelle B1 Module, Spezielle Störungslehre: Krankheiten des Kindesalters, Behinderung, B2 Module, VorahmungMitahmung-Nachahmung-Verbindung, Leibnahe und geistnahe seelische Spiegelungsprozesse in der Entwicklung, Power Point Presentation, slide no. 16, Master Studies, Art Therapy, Alanus Hochschule für Kunst und Gesellschaft University, Alfter, Bonn, 2015.

${ }^{15}$ Ibidem, slide no. 26.

${ }^{16}$ Ibidem

${ }^{17}$ Cristian Nae, op.cit., pp.102-120.

${ }^{18}$ Janine Chasseguet-Smirgel, Psihanaliza artei și a creativității, Marius Chivu, Silviu Dragomir, Vasile Dem Zamfirescu (editors), translation from French to Romanian by Georgeta Mitrea, Trei Publishing House, București, 2002, pp. 86-90.

${ }^{19}$ K.-U. Adam, I Allgemeine theoretische Grundlagen, Springer Publishing House, Berlin, 2006, < <ttp://www.krammerbuch.at/bookData/pdfs/adam_lesepr.pdf $>(29.05 .2016,17: 34)$. 
two instances are not developed yet. The beginning of awareness marks the beginning of a development which leads to a painful experience that is felt like a real shock; once the prenatal stage is over, the baby breaks out of his mother's body (Id) in order to enter the physical world and since that very moment his native stage begins (Ego) and Superego becomes a component part of it which is willingly "built" by the educational and social factors. These three instances are connected to each other during the entire life as a whole in comparison to the prenatal stage when this connection is not fully defined, there is no clear separation among these three instances.

Remarkable is the fact that in the Middle Ages, the painter began to ask himself existential questions that materialized during Renaissance in the acute desire to faithfully represent the reality from an anatomic point of view, self-portrait having a fluctuating and complex development that gradually focused on: metamorphoses (El Greco, Fancisco de Goya), anamorphosis (Pietro da Cortona), brutal reality (Gustave Courbet) and, last but not least, on atmospheric effects, in which human being becomes just a pretext (Claude Monet), or on effects of deconstructed forms (Paul Cézanne). The interest consisted in identifying the real reasons behind painters' inner need to use their own faces as a pretext for expressing personal affections, filtered, of course, from the point of view of artistic styles conditioned by the atmosphere of that epoch in which the artist lived, and consisted also in outstanding specific biographical experiences that are connected to their painted self-portraits.

\section{Portrait in the art of Middle Ages: Romanic, Gothic Periods}

The medieval age ( II-XIV centuries) was a difficult period caused by the invasions of Germanic tribes (Goths, Vandals, Saxons and Vikings) and wars, being characterized by a moral and spiritual crisis ${ }^{20}$ which was also reflected in portraiture. This was also due to simple people's unjustified and naive fear towards the magical art of portrait which constituted a real impediment to finding patterns, as there was a strong and interesting belief that once the character was transposed on a canvas, a part of the character's soul was lost:

Who doesn't know that most of people used to believe until a while ago, that «painting» a character was equivalent to «stealing his soul», and

12 Constantin Enăchescu, Tratat de psihopatologie, Tehnică Publishing House, București, 2000, p. 17.

${ }^{20}$ D. N. Zaharia, Istoria artei antice și medievale, $2^{\text {nd }}$ Edition, Artes Publishing House, Iaşi, 2008., p. 141. 
that the person who would let his face to be painted was about to die in 40 days $^{21}$,

but gradually people became more open-minded and stopped having this conviction.

Self-portrait had an interesting evolution, as the medieval artists bacame more aware of their own artistic abilities; monk Eadwine from Canterbury painted his self-portrait from his memory, being the first selfportrait attempt in the history of universal $\operatorname{art}^{22}$. This illustrates the author's contextualization within the initials of his name, represented by a small workshop, in which the artist surprises himself during the painting process with the utensils in his both hands. This self-representation is a Romanic one $^{23}$, since one can notice the superficial rendering of shadows, the precarious perspective and the clumsy drawing, as well as the stylized and naive representation, but remarkable is the attempt of representing a more expressive and humanised character ${ }^{24}$ which compensates all these technical deficits, highlighting the separation from the Byzantine style canons. On a closer inspection as for the character's facial expression, one can notice the artist's concentration during his work expressed by his gaze towards the letter $\mathrm{R}$ which is being painted; the artist keeps the paintbrush in his right hand with much skill and trust in his own forces, and in the other hand a supporting tool (german Malstock, Malerstock) and a color container. In fact, the painter creates his own inner space, a personal universe that offers protection, safety and self-confidence.

During the Gothic period $\left(12^{\text {th }}-15^{\text {th }}\right.$ centuries), self(-portrait) as a genre experienced an innovative interpretation, being perceived not only from a spiritual perspective but also from a physical one, and in this context the theologian Thomas d'Aquino distinguished with lucidity and intelligence the spiritual beauty from the profane one, challenging a new aesthetics: One thing is considered to be beautiful when it has a bodily or spiritual sparkle of its own kind. ${ }^{25}$ Also, the Italian poet and philosopher Dante Alighieri, who had a nice friendship relationship with d'Aquino, had the same opinion (And when the body is well-formed and prone, then each part is beautiful, as well as the entire body... ${ }^{26}$ ), thus pleading for a more obvious detachment from the Byzantine tradition.

\footnotetext{
${ }^{21}$ Adrian-Silvan Ionescu, Mişcarea artistică oficială în România secolului al XIX-lea, Bucureşti, Noi Media Print Publishing House, București, 2008, p.9, apud Gheorghe Popovici, Exposiţiunea de pictură de la Ateneu, „Lupta”, No. 1970/4 April, 1893.

22500 Self-Portraits, Phaidon Press Limited Publishing House, Londra, 2000, p. 14.

${ }^{23}$ Romanic style appeared in $10^{\text {th }}-12^{\text {th }}$ centuries.

${ }^{24}$ D. N. Zaharia, op.cit., p.229.

${ }^{25}$ Valentin Sava, Judecata estetică și portretul în pictura de șevalet, Artes Publishing House, Iași, 2005, p.49, apud Despre Numele Divine (translation by M. Gramatopol).

${ }_{26}$ Ibidem, p.50, apud Dante Alighieri, Divina Comedie.
} 

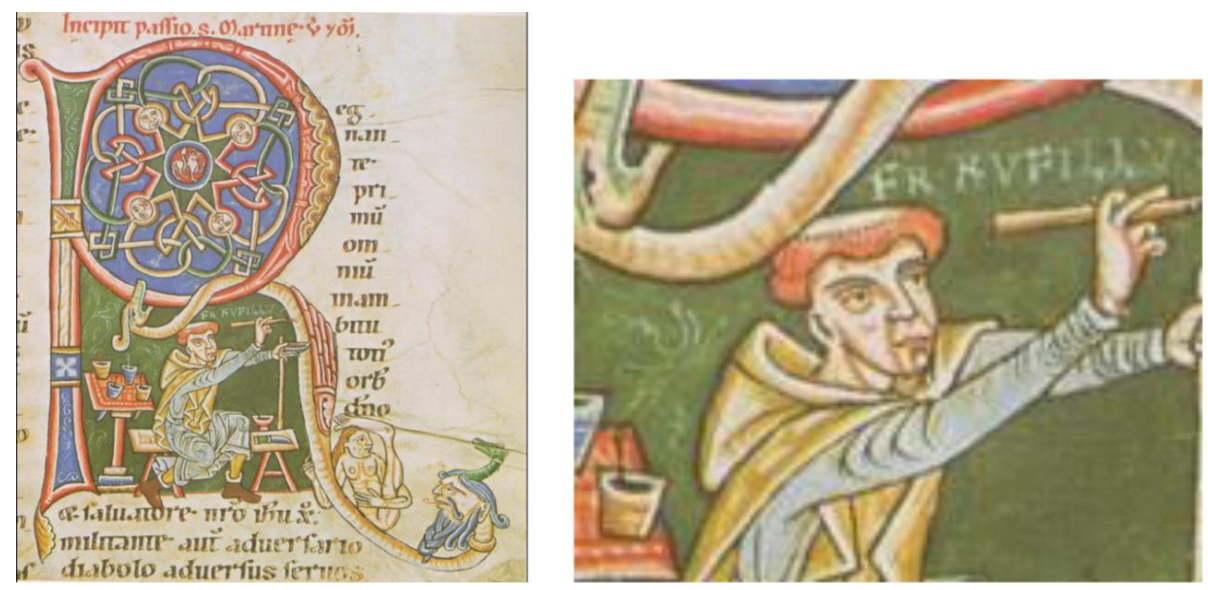

Fig. 5 Rufilus brother, Inițiala $R$, miniature from a Legendar, $13^{\text {th }}$ century, Bodmeridiana Library, Geneva ${ }^{27}$

Giotto di Bondone, an artist on the border between medieval and Renaissance period, demonstrated an authentic ability to represent emotions, by humanizing character's traits, which implied the introduction of character's study, thus giving the viewer the opportunity to decipher intense experiences of joy or dramatic states of mind:

Even if the memory of the Byzantine "Greek manner" was very strong, Giotto «rethink»s it, by «making some changes» and by checking the character's representative value when it comes to reality confrontation ${ }^{28}$.

One can confirm that since this era, signs of self-awareness have become more prominent and self-portrait gained its recognition during Renaissance period. Painters unconsciously felt the need for identity affirmation and recognition and the self-portraiture attempt began to satisfy all these requirements, becoming later an indispensable tool in an artist's creation.

\footnotetext{
${ }^{27}$ Simon Abrahams, Brother Rufillus' Self-Portrait (c. 1170-1200) $<$ https://www.academia.edu/9129386/Brother_Rufillus_Self-Portrait_c._1170-1200_> (02.08.2016, 00:15), 500 Self Portraits, Phaidon Press Limited, Londra, Anglia, 2000, p.14, Victor Ieronim Stoichiță, Instaurarea tabloului. Metapictura în zorii Timpurilor Moderne, translation from French by Andrei Niculescu, Meridiane Publishing House, Bucureşti, 1999, p. 233.

${ }^{28}$ Ovidiu Drimba, Istoria culturii și civilizației, $7^{\text {th }}$ volume, Saeculum I.O. Publishing House, București, 2007, p. 308.
} 


\section{Portraiture representations in the art of the Romanian Countries since ancient times until Modern Age: Antiquity, the Middle Ages}

Generally speaking, ancient people used to paint animals, avoiding the representation of human silhouettes, since they believed that human soul drips out of the human body once a character is being painted.

The first self-portrait in the history of Romanian art was recorded in the $14^{\text {th }}$ century and belongs to painter Grozie ${ }^{29}$; it's considered to be the first attempt to reproduce the three-dimensionality of the human body through the interference of the shaded parts with the bright ones, under the influence of the Gothic style:

Unlike Orthodox churches which promoted Byzantine canons and established a precise iconographic order, Gothic paintings are very free from this point of view and it's difficult to establish certain distribution rules. ${ }^{30}$

The appearance of this first self-portrayal intention represents a real sign of self-awareness of one's own artistic value and affirmation of ego. Grozie is represented next to Saint Nicholas ${ }^{31}$ to whom is praying and appears in the light of a pronounced spirituality, betrayed by his eyes raised to heaven, as well as by his praying hands. His meditative and pious face symbolizes his detachment from the profan world in order to re-establish his connection with Divinity, but also represents the egotic desire for selfrecognition of artistic value.

In the $15^{\text {th }}$ century, a less rigid compositional style was asserted, a major role in this direction being played by monk Gavril Uric ${ }^{32}$ from Neamt monastery which was a real source of inspiration for future Moldavian generations of miniature and easel paintings. He succeeded in expressing the characters' inner feelings, the relaxed line and the decorative borders encouraging the emergence of profane tendencies in Romanian (self-) portraiture.

\footnotetext{
${ }^{29}$ Vasile Florea, Istoria artei românești veche și medievală, in 3 volumes: $1^{\text {st }}$ volume, Hyperion Publishing House, Chișinău, 1991, p. 100.

${ }^{30}$ Ibidem, p.101, apud Vasile Drăguț, Arta românească, Bucureşti, 1982, p. 126

31 Vladimir Agrigoroaei, Picturile de la Strei. Sau cum a sorbit Grozie din apa vieții $<$ http://totb.ro/picturile-de-la-strei-sau-cum-a-sorbit-grozie-din-apa-vietii/> (04.08.2016,00:05)

32 Vasile Drăguț, Vasile Florea, Dan Grigorescu, Marin Mihalache, Pictura românească în imagini, Meridiane Publishing House, Bucureşti, 1970, p. 25.
} 


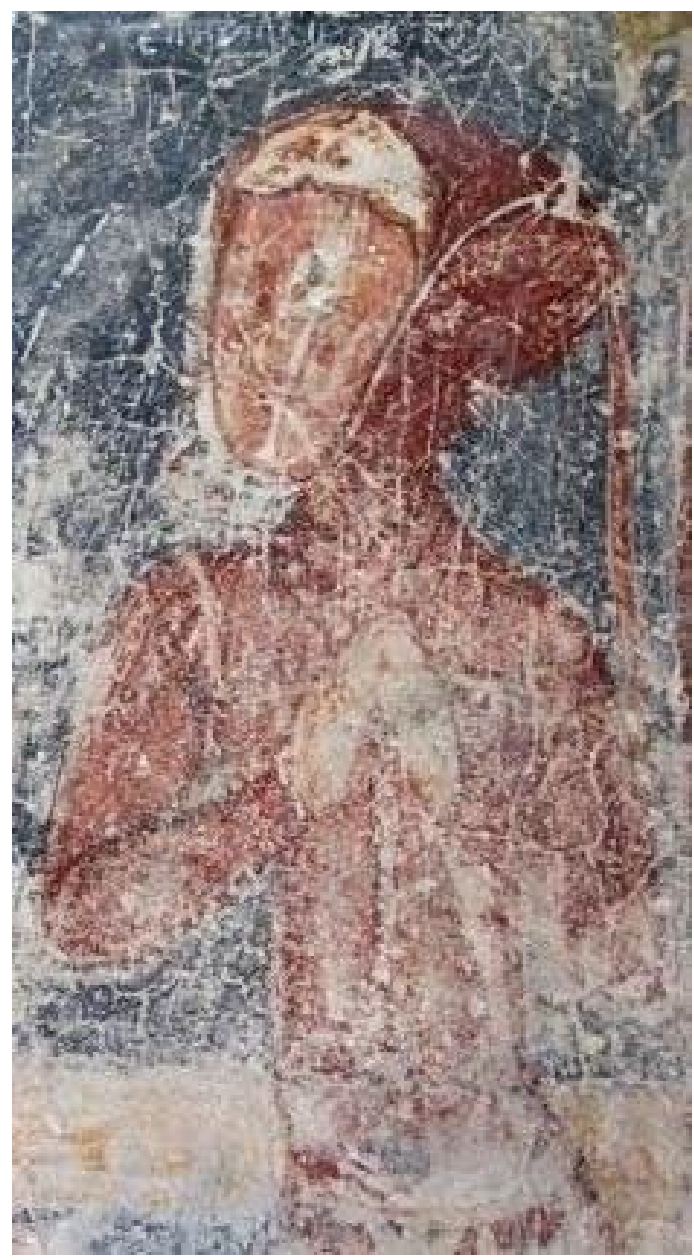

Fig. 2 Grozie Painter, Self-portrait of Grozie the master, fresco, $16^{\text {th }}$ century, Strei church, Hunedoara county ${ }^{33}$

A remarkable portrait representation belongs to Metropolit Grigorie Roșca from Voroneţ monastery, whose appearance next to Saint Daniil Sihastrul, Ștefan cel Mare's confessor, can be understood as a response to his pleading for the independence of our country ${ }^{34}$ and for gaining a moral and artistic autonomy; it's a leitmotif that is present also in the scene of Beleaguerment from Humor monastery, where there is Toma' s self-portrait from Suceava. ${ }^{35}$ The obscure historical events during the $16^{\text {th }}$ century

\footnotetext{
${ }^{33}$ Ibidem.

${ }_{34}^{34}$ Ibidem, pp. 192, 376, fig. 348.

${ }^{35}$ Ibidem, p.369.
} 
encouraged the collaboration of Romanian artists with foreign artists, resulting in the individualization of human figure, as one can notice in the iconographic scenes from the orthodox cathedral Curtea de Argeș ${ }^{36}$, which signals the beginning of profane painting. Important is to mention that in this period appeared the first artist's signature on the monastery frescoes, as it denotes a beginning of artist's self-awareness: And I, the great David the painter, wrote [painted], together with my son Radislav ${ }^{37}$. The usage of the personal pronoun $I$ highlights the authenticity of artist's status from that of the craftsman's a which was officially recognised only in the middle of the $19^{\text {th }}$ century, whereas in the universal art this differentiation took place in the maturity period of Renaissance.

It can be concluded that the attempts of (self-) representation appeared since ancient times as an unconscious necessity of self-affirmation, in order to annihilate anonymity. The intention consisted in studying the emergence of first self-portraiture attempts, taking into consideration the psychological aspects which can help finding out specific explanations regarding this strong necessity of (self-) representation.

\section{Bibliography:}

\section{Books:}

Cârneci, Magda, Artele plastice în România 1945-1989. Cu o addenda 1990-1989, $2^{\text {nd }}$ Edition, Ioana Aneci (editor), Polirom Publishing House, Iaşi, 2013.

Drăguț, Vasile, Florea, Vasile, Grigorescu, Dan, Mihalache, Marin, Pictura românească în imagini, Meridiane Publishing House, Bucureşti, 1970.

Dună, Raluca, Eu, autorul. Reprezentări auctoriale în literatură şi pictură. Din Antichitate până în Renaștere, Ioan Cristescu, Cosmin Perța (editors), Tracus Arte Publishing House, București, 2010.

Florea, Vasile, Istoria artei românești veche și medievală, in 3 volumes: $1^{\text {st }}$ volume, Hyperion Publishing House, Chişinău, 1991.

Gombrich, E.,H., Istoria Artei. Aproape la fel de cunoscută ca «Mona Lisa», translation by Nicolae Constantinescu, Art Publishing House, Bucureşti, 2012.

Tzigara-Samurcaş, Al., Scrieri despre arta românească, Vasile Florea (editor), Meridiane Publishing House, București, 1987.

Zaharia, D.N., Istoria artei antice și medievale, $2^{\text {nd }}$ Edition, Arte Publishing House, Iași, 2008.

Zaharia, D.N., Istoria artei renascentiste, Artes Publishing House, Iași, 2008.

Zaharia, D.N., Istoria artei moderne, $2^{\text {nd }}$ Edition, Arte Publishing House, Iași, 2007.

Zaharia, D.N., Istoria artei contemporane, Artes Publishing House, Iași, 2008.

***, Der Künstler über sich in seinem Werk (Artistul despre el in opera sa), Matthias Winner (editor), VCH Publishing House, Acta Humaniora, Weinheim, 1992.

\footnotetext{
${ }^{36}$ Vasile Drăguț, Vasile Florea, Dan Grigorescu, Marin Mihalache, op. cit., pp. 46-47.

${ }^{37}$ Vasile Florea, op.cit., p.320.
} 
***, That's me! Das Portrait von der Antike bis zur Gegenwart (Acesta sunt eu! Portretuldin Antichitate până în prezent), Jaape Braakke (editor), Niedersächsisches Landesmuseum Hannover Publishing House, Hannover, 2010.

\section{Dictionaries:}

Drăguț, Vasile, Dicționar enciclopedic de artă medievală românească, Științifică și Enciclopedică Publishing House, Bucureşti, 1976. 